\title{
Cavitary Pulmonary Lesion Due To COVID-19 Infection Mimicking Lung Cancer
}

\author{
Akciğer Kanserini Taklit Eden COVID-19 Enfeksiyonuna Bağlı Kaviter \\ Pulmoner Lezyon
}

Seher Satar, Mustafa Engin Sahin, Pinar Ergun

\begin{abstract}
Various radiological findings have been detected associated with SARS-CoV-2 (COVID-19). We present here a middle-aged patient with a thick-walled cavitary lesion resembling lung cancer radiologically after COVID-19. Most of the etiological factors for cavitary lung lesions were investigated, and no specific cause was found. After empirical dual antibiotic treatment, the cavitary and the nodular lesion were observed to regress almost completely in control thorax computed tomography. For this reason, we considered the cavity of our patient as a late complication of COVID-19 and also we advocate the importance of monitoring patients with clinical data and laboratory values as well as radiological findings after contracting COVID-19.
\end{abstract}

Key words: COVID-19, cavitary lesion, lung cancer.

\section{Özet}

Coronavirus hastalığı 2019 (COVID-19) sırasında çeşitli radyolojik bulgular tespit edilebilir. COVID-19 sonrası radyolojik olarak akciğer kanserini düşündüren kalın duvarlı kaviter lezyonu olan orta yaşlı bir hastayı sunuyoruz. Hastamızda kaviter akciğer lezyonlarının etiyolojik faktörlerinden bir çoğu araştıııldı ve herhangi spesifik bir neden bulunamadı. Ampirik ikili antibiyotik tedavisi sonrası kontrol toraks bilgisayarlı tomografisinde kaviter ve nodüler lezyonların tama yakın gerilediği gözlendi. Bu nedenle hastamızın kavitesini COVID-19'un geç bir komplikasyonu olarak değerlendirdik ve ayrıca COVID-19 enfeksiyonu sonrası hastaların klinik verileri ve laboratuvar değerlerinin yanı sıra radyolojik bulguları ile de izlenmesinin önemini vurguladık.

Anahtar Sözcükler: COVID-19, kaviter lezyon, akciğer kanserin.

Health Sciences University Atatürk Chest Diseases and Thoracic

Sağlık Bilimleri Üniversitesi Atatürk Göğüs Hastalıkları ve

Surgery Health Application Research Center, Ankara, Turkey Göğüs Cerrahisi Sağlık Uygulama Araştırma Merkezi, Ankara

Submitted (Başvuru tarihi): 19.06.2021 Accepted (Kabul tarihi): 02.09.2021

Correspondence (iletișim): Seher Satar, Health Sciences University Atatürk Chest Diseases and Thoracic Surgery Health Application Research Center, Ankara, Turkey

e-mail: sehersatar@yahoo.com

*This case report was accepted and presented as an oral presentation Ankara International Congress on Scientific Research-V on November 10, 2021, and its summary was published in the congress book. 
A new infectious disease caused by severe acute respiratory syndrome coronavirus 2 (SARS-CoV-2) that was given the name COVID-19 emerged in late December 2019 (1). COVID-19 is associated with lower mortality, a stronger secret structure and a greater transmission capacity than severe acute respiratory syndrome (SARS) and Middle East respiratory syndrome (MERS) (2). According to the WHO weekly analysis published on August 10, 2021, the total number of COVID-19 cases worldwide surpassed 200 million just six months after reaching 100 million, and reported more than 4.2 million new cases and more than 65,000 new deaths in that week alone, representing a slight increase on the previous week (3). It is very difficult to diagnose the findings of COVID-19, which mostly progresses as a respiratory system infection on conventional postero-anterior (PA) chest radiography. As such, computed tomography (CT) imaging, especially high-resolution lung tomography (HRCT), is very important in the diagnosis of the disease. The most common radiological findings include single or multiple lesions, patchy or segmental ground-glass opacities (93.3\%), and reticular streaks concentrated primarily in the peribronchovascular and subpleural areas. In addition, interlobular septal thickening, and in rare cases, pleural effusion and enlarged mediastinal lymph nodes can also be seen (4). The sensitivity of nasopharyngeal swab samples taken for the diagnosis of the disease is not as high as expected, and so the importance of thoracic CT imaging for the diagnosis and follow-up of the disease is understood.

\section{CASE}

Although asymptomatic, after learning that his wife was COVID-19 positive, our 40-year-old male patient underwent a real-time polymerase chain reaction ( $r+P C R)$ test considering the presence of contact. The nasopharyngeal swab was positive for severe acute respiratory syndrome coronavirus 2 (SARS-CoV-2), and so the patient was started on 5-day oral favipiravir tablet treatment in October 2020 and was recommended to follow the isolation rules at home. Since he had no complaints and no comorbid disease history, the patient did not undergo any laboratory or imaging tests, but was advised to follow up his symptoms and to apply to the health institution if necessary. One week after the completion of favipiravir treatment, he developed complaints of cough, sore throat, back pain and a very small amount of hemoptysis. After presenting to a health institution where a non-contrast thorax computed tomography was performed, the patient was referred to our hospital for further examination and treatment. He had no fever or sputum at this time.

It was learned from the patient that he was employed in animal husbandry, smoked 22 packs/years, quit for 2 years, had no known comorbid disease and had not undergone any surgical procedure other than an appendectomy performed 17 years earlier. There was no obvious pathological physical examination finding. Laboratory tests were requested, including hemogram, biochemistry, sedimentation, C-reactive protein (CRP), D-dimer, PA chest radiography (Figure 1), acid-fast bacilli (AFB) examination, and sputum non-specific bacterial and fungal culture tests, the results of which are presented in Table 1. The acid-fast bacilli examination and the microbiological cultures of the sputum were found negative. A thoracic CT of the patient revealed a thick-walled cavitary lesion with a diameter of $3.5 \mathrm{~cm}$ in the right upper lobe accompanied by an area of ground-glass density and a $17 \mathrm{~mm}$ nodular lesion in the subpleural region of the same lobe. The thoracic CT images are presented in Figure 2. An analysis of the patient's retrospective health data from the Health Ministry database revealed no previous thoracic images.

Based on the findings, it was decided to conduct an etiological investigation of the cavitary lesion that had developed post-COVID in the hospital. Dual nonspecific intravenous antibiotic therapy (3rd generation cephalosporin and clarithromycin) and subcutaneous low molecular weight heparin treatment were applied to the patient due to the high infection markers and D-dimer levels. The patient was hospitalized, and the cause of the cavitary lesions in the lung was investigated. Collagen tissue markers were normal, sputum AFB results were negative, and no pathogen was found in non-specific and fungal cultures of sputum. The antigen test for hydatid cyst was taken from the patient and it was negative. A Positron Emission Tomography/CT (PET/CT) was performed with a pre-diagnosis of malignancy, although the patient had no previous finding compatible with malignancy and no positive result in our tests for non-cancerous infectious (bacterial, fungal, tuberculosis) causes, connective tissue and vasculitic diseases, all of which can cause cavitary lesions. The PET/CT images revealed a maximum Standard Uptake Value (SUVmax) of 11.13 in a cavitary lesion with an irregular wall structure measuring approximately $30 \times 17 \mathrm{~mm}$ with ground-glass density areas on the periphery of the upper lobe of the right lung, and SUV: 3.63 in a $14 \times 8 \mathrm{~mm}$ nodule in the anterior of the right upper lobe of the right lung. In addition, low-moderate in- 
creased metabolic activity involvement (SUVmax: 2.664.19) was observed in the bilateral superior jugular, bilateral axillary, right lower paratracheal and bilateral hilar lymph nodes. A fiberobtic bronchoscopy (FOB) revealed no pathological findings. Bronchial lavage was taken from the right upper lobe anterior that pathology identified as an inflammatory process. Tissue sampling through endobronchial ultrasound (EBUS) was planned for the lymph nodes specified on PET/CT, but no transbronchial needle aspiration (TBNA) was performed upon the detection of uncertain isoechoic reactive lymph nodes in the left interlobar and subcarinal areas in EBUS. Since the clinical findings of the patient improved with empirical antibiotic treatment and no pathological findings were found in all examinations, it was decided that the patient's outpatient antibiotic treatment was extended and discharged. Thoracic CT performed within the first month of discharge (Figure 3) revealed that the cavitary lesion in the right upper lobe had disappeared, minimal infiltrative densities were persisting, and the size of the nodular lesion in the right upper lobe anterior segment had decreased.

\section{DISCUSSION}

Although real-time polymerase chain reaction tests have been approved by the Centers for Disease Control (CDC) and $\mathrm{WHO}$ as the optimum diagnostic approach, with moderate sensitivity and high specificity for the confirmation of COVID-19, a large number of false-negative results have been recorded (5). The contribution of thoracic $\mathrm{CT}$ examination to diagnosis thus cannot be denied $(6,7)$, nor the important role it can play in the management of COVID-19 pneumonia (8). The present study supports the need for thoracic $C T$ in suspicious cases in the follow-up of a COVID-19 diagnosis.

The information garnered from radiological findings of COVID-19 is getting clearer every day as the clinical experience of healthcare professionals increases. The prevalence of CT abnormalities in cases of COVID-19 varies depending on the stage and severity of the disease. An earlier study found that $\mathrm{CT}$ findings vary according to age groups and disease severity. Ground-glass opacities were found to be more common in young adults, consolidations and multilobar involvement were found to be more common in older adults, and consolidations, effusions, atelectasis, "white out" lungs and ARDS are more common in patients with severe or critically severe pneumonia (9).

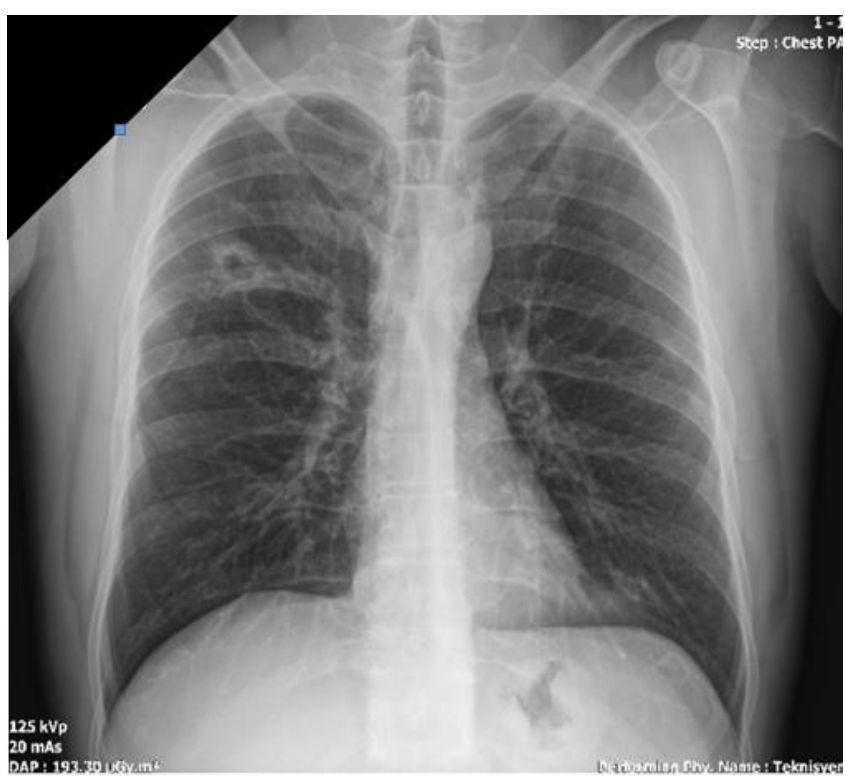

Figure 1: Postero-anterior chest radiography at the time of initial hospital admission showing the cavitary lesion

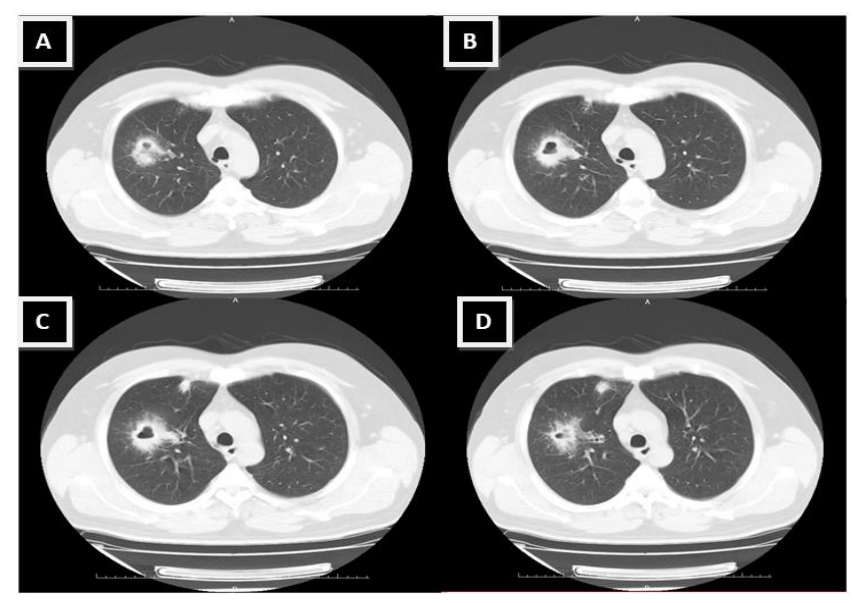

Figure 2: First lung CT, taken 1 month after the completion of COVID19 treatment. A cavitary mass lesion of $3.5 \mathrm{~cm}$ diameter, cavitation in the center, and consolidation - ground-glass areas - on the periphery observed in the right lung upper lobe anterior. In addition, a separate nodular lesion of $17 \mathrm{~mm}$ diameter with irregular-spiculated contours can be seen in the subpleural area in the anterior of the upper lobe

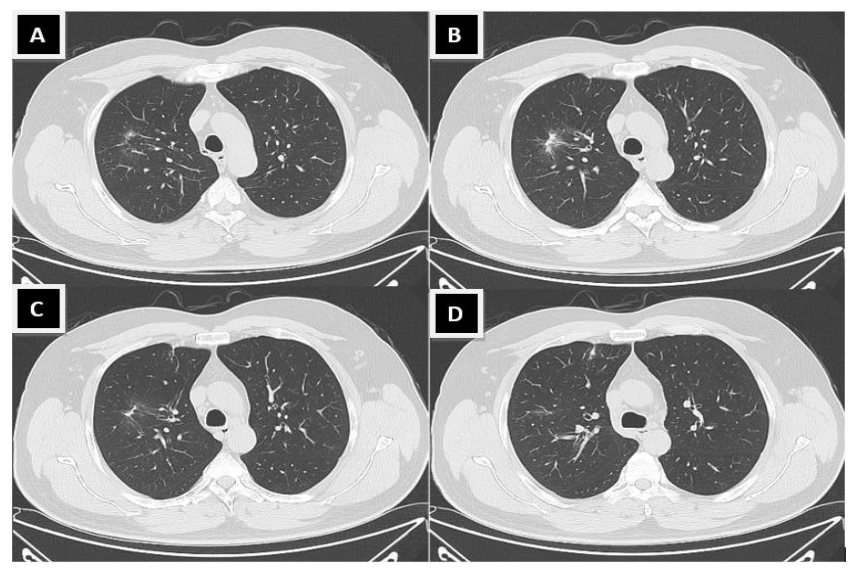

Figure 3: Thoracic CT images taken 1 month after discharge 
Table 1: Some of our patients' initial laboratory results

\begin{tabular}{|c|c|c|c|}
\hline & & Result & Normal Range \\
\hline \multirow[t]{6}{*}{ Hemogram } & White blood cells & 5900 & $(4.6-10.2) \times 103 / \mu \mathrm{L}$ \\
\hline & Lymphocyte & 2350 & $(0.6-3.4) \times 103 / \mu \mathrm{L}$ \\
\hline & Neutrophil & 3030 & $(2-6.9) \times 103 / \mu \mathrm{L}$ \\
\hline & Eosinophil & 120 & $(0-0.7) \times 103 / \mu \mathrm{L}$ \\
\hline & Hemoglobin & 14.0 & $(14.1-18.1) \mathrm{g} / \mathrm{dL}$ \\
\hline & Platelet & 435 & $(142-424) \times 103 / \mu \mathrm{L}$ \\
\hline \multirow[t]{7}{*}{ Biochemistry } & Glucose & 94 & $70-106 \mathrm{mg} / \mathrm{dL}$ \\
\hline & $\begin{array}{l}\text { Blood Urea Nitrogen } \\
\text { (BUN) }\end{array}$ & 18 & $8-20 \mathrm{mg} / \mathrm{dL}$ \\
\hline & Creatinine & 0.95 & $0.84-1.25 \mathrm{mg} / \mathrm{dL}$ \\
\hline & $\begin{array}{c}\text { Aspartate aminotrans- } \\
\text { ferase (AST) }\end{array}$ & 27 & $10-50 \mathrm{IU} / \mathrm{L}$ \\
\hline & $\begin{array}{c}\text { Alanine amotransfer- } \\
\text { ase (ALT) }\end{array}$ & 43 & 10-50 IU/L \\
\hline & Troponin & $<2.50$ & $0-58.5 \mathrm{ng} / \mathrm{L}$ \\
\hline & Ferritin & 191.3 & $22-322 \mathrm{ng} / \mathrm{ml}$ \\
\hline \multicolumn{2}{|l|}{ Sedimentation } & 74 & $0-20 \mathrm{~mm} / \mathrm{saat}$ \\
\hline \multicolumn{2}{|l|}{ C-reactive protein (CRP) } & 52.87 & $0-5 \mathrm{mg} / \mathrm{L}$ \\
\hline \multicolumn{2}{|l|}{ D-dimer } & 0.5 & $0-0.44 \mathrm{mg} / \mathrm{L}$ \\
\hline
\end{tabular}

In a systematic review and meta-analysis, the radiological findings of COVID-19 were classified according to their frequency. First of all, the incidence of normal chest CT findings in symptomatic COVID-19 patients was determined to be approximately $10.6 \%$, and $46 \%$ in asymptomatic patients. The study went on to report that the CT findings identified in over $70 \%$ of cases were, in order of prevalence, posterior predilection (90\%), ground-glass opacity $(81 \%)$, bilateral abnormalities $(75.8 \%)$, left lower lobe involvement $(73.1 \%)$, vascular thickening $(72.9 \%)$ and right lower lobe involvement (72.2\%). The intermediate CT findings, with a frequency of $10-70 \%$, included, in order of prevalence, consolidation (51.5\%), septal thickening and/or reticulation (49.6\%), linear opacity (40.7\%), air bronchogram (40.2\%), crazy-paving pattern (34.9\%), pleural thickening (34.7\%), halo sign (34.5\%), bronchiectasis $(24.2 \%)$, nodules (19.8\%), bronchial wall thickening (14.3\%) and reverse halo sign (1 1.1\%). Chest CT findings with low incidence $(<10 \%)$ in RT-PCR test-proven COVID-19 cases included, in order, pleural effusion (5.2\%), lymphadenopathy (5.1\%), tree-in-bud sign (4.1\%), central lesion distribution (3.6\%), pericardial effusion $(2.7 \%)$ and cavitating lung lesions $(0.7 \%)(10,11)$. As indicated in this meta-analysis, lung cavity lesion development is a very rare finding in COVID-19, compelling us to report on our case who was identified with a cavitary lung lesion while mildly symptomatic following the treatment during active stage of the disease.

Cavitary lung lesions can generally be seen in both benign and malignant diseases, with the most common causes being tuberculosis, bacterial-fungal infections, pulmonary embolism, collagen-vascular diseases and lung malignities.

Such lung cavities can be observed especially in the presence of bacterial infections caused by staphylococcus aureus, gram negative bacteria (such as Klebsiella, proteus and pseudomonas) and anaerobic microorganisms. Large solitary abscesses with no underlying lung disease are usually seen in anaerobic infections, and are especially common in people with poor oral hygiene, and in those with alcohol and drug use disorders. Based on the preliminary diagnosis, we first examined for bacterial and fungal infections in our patient, but identified no growth in the culture of any of our sputum or bronchial lavage samples. A previous study reported cavity incidences in $10-30 \%$ of primary tuberculosis cases (12), however, the 
bronchial lavage and sputum AFB examinations of our patient, who had been referred six times for mycobacterium tuberculosis, revealed no pathology.

Recent studies have identified several important procoagulant events, especially pulmonary embolism (PE), which can progress with a life-threatening prognosis in COVID19 patients. It has long been known that the areas of pulmonary infarction that can develop after a pulmonary embolism, can lead to the development of cavitary lesions, with an incidence of $4-7 \%$, with factors such as old age, heart failure and chronic lung disease reported as risk factors for cavitation development (13). Our patient was considered to be at low risk of pulmonary embolism based on his age, and due to the lack of any accompanying disease, no active smoking, no current medications, no recent travel history, no history of hospitalization or intensive care hospitalization during infection, and being mobile. Cavity development due to pulmonary embolism was thus excluded from the differential diagnosis of our patient.

Given the potential for cavities in the lung involvement of many connective tissue diseases or vasculitis, especially rheumatoid arthritis, Wegener granulomatosis and ankylosing spondylitis (14), all collagen tissue markers were requested considering the possibility of a previously undiagnosed connective tissue disease in our patient, but all were negative.

Malignancies are one of the most common causes of solitary cavitary lesions in the lung (15), and can be of various sizes, with a cavity wall wider than $24 \mathrm{~mm}$ being particularly suggestive of malignancy. Some $10-15 \%$ of all bronchial malignities develop cavitary lesions. Due to the thick-walled cavity identified in our patient, his exsmoker status and the presence of hemoptysis among the symptoms, lung cancer was indicated the strongest among our differential diagnoses. Consequently, examinations were made for confirmation, but no data supporting lung cancer was identified in the patient in PET/CT, FOB or EBUS findings.

As mentioned previously, cavitary lesions in the lung in COVID-19 are rare, and in the earliest publications COVID-19 was excluded based on the presence of cavitary lesions (16). As knowledge and experience of COVID-19 increased, knowledge is renewed, and there have been recent publications on cases of COVID-19 with cavitary lesions. Pasero et al. (17) first reported on a case diagnosed with COVID-19 that developed pulmonary mucormycosis with extensive cavitary lesions. Another article described a case of COVID-19 pneumonia in a young, healthy male patient complicated by cavitary lesions and pneumothorax (18). In the present study, we concluded that our patient's cavity was a complication of COVID-19 after all other known cavitary lesion diagnoses were excluded.

The mechanism behind lung cavity development associated with COVID-19 is still unclear. Ackerman et al. (19) detected microvascular pulmonary endothelialitis in a COVID-19 autopsy series, and it is a long well-known fact that small vessel vasculitis causes cavity (20). The microangiopathies known to occur in COVID-19 infection can therefore be considered a plausible mechanism for cavitary lesion development in the lung. Furthermore, as another potential reason for cavities in COVID-19, mechanical ventilation has been linked to the development of cystic lesions and pneumothorax, with degradation of alveolar walls after ischemic parenchymal damage and consolidation resulting in pneumatocele formation $(16,21)$. In another study, it was reported that cavitary lung lesions in patients with COVID-19 may be associated with mechanical ventilator-induced lung injury, barotrauma (pneumothorax, pneumomediastinum) being reported in up to $15 \%$ of especially young patients who received invasive mechanical ventilation support with a diagnosis of COVID-19 (22). Ventilator-induced lung injury was not considered in our patient due to the absence of any intensive care hospitalization or invasive mechanical ventilation support. We evaluated our patient as a rare case of lung cavity due to COVID-19 with a ground glass area around the thick-walled cavitary lesion, spontaneous absorption without steroid administration, and long and strong antibiotic treatment.

\section{CONCLUSION}

In the follow-up of patients diagnosed with COVID-19, it should be kept in mind that cavitary lesions may develop due to COVID-19 infection after all differential diagnoses are excluded in the presence of cavitary lesions. Thinsection HRCT should thus not be avoided during followup when necessary, as it provides detailed imaging for the follow-up of complications that may occur after the active period of the disease.

\section{CONFLICTS OF INTEREST}

None declared.

\section{AUTHOR CONTRIBUTIONS}

Concept - S.S., M.E.S., P.E.; Planning and Design - S.S., M.E.S., P.E.; Supervision - S.S., M.E.S., P.E.; Funding - 
S.S., M.E.S., P.E.; Materials - S.S., M.E.S., P.E.; Data Collection and/or Processing - S.S., M.E.S., P.E.; Analysis and/or Interpretation - S.S., M.E.S., P.E.; Literature Review - S.S., M.E.S., P.E.; Writing - S.S., M.E.S., P.E.; Critical Review - S.S., M.E.S., P.E.

\section{YAZAR KATKILARI}

Fikir - S.S., M.E.S., P.E.; Tasarım ve Dizayn - S.S., M.E.S., P.E.; Denetleme - S.S., M.E.S., P.E.; Kaynaklar - S.S., M.E.S., P.E.; Malzemeler - S.S., M.E.S., P.E.; Veri Toplama ve/veya İşleme - S.S., M.E.S., P.E.; Analiz ve/veya Yorum - S.S., M.E.S., P.E.; Literatür Taraması - S.S., M.E.S., P.E.; Yazıyı Yazan - S.S., M.E.S., P.E.; Eleştirel Inceleme - S.S., M.E.S., P.E.

\section{REFERENCES}

1. World Health Organization. Coronavirus. https://www. who.int/health-topics/coronavirus\#tab=tab_1. Accessed June 6, 2020.

2. Corman VM, Landt $O$, Kaiser M, Molenkamp R, Meijer A, Chu DK, et al. Detection of 2019 novel coronavirus (2019-nCoV) by real-time RT-PCR. Euro Surveill 2020; 25: 2000045. [CrossRef]

3. World Health Organization (WHO). Weekly epidemiological update on COVID-19 - 10 August 2021. Edition 52. https://www.who.int/publications/m/item/weeklyepidemiological-update-on-covid-19---10-august-2021.

4. Dai WC, Zhang HW, Yu J, Xu HJ, Chen H, Luo SP, et al. CT Imaging and differential diagnosis of COVID-19. Can Assoc Radiol J 2020; 71:195-200. [CrossRef]

5. Lippi G, Simundic AM, Plebani M. Potential preanalytical and analytical vulnerabilities in the laboratory diagnosis of coronavirus disease 2019 (COVID-19). Clin Chem Lab Med 2020; 58:1070-6. [CrossRef]

6. Fang $Y$, Zhang $H, X_{i e} J$, Lin $M$, Ying $L$, Pang $P$, et al. Sensitivity of chest CT for COVID-19: comparison to RT-PCR. Radiology 2020; 296:E1 15-7. [CrossRef]

7. Ai T, Yang Z, Hou H, Zhan C, Chen C, Lv W, et al. Correlation of chest $C T$ and $R T-P C R$ testing in coronavirus disease 2019 (COVID-19) in China: a report of 1014 cases. Radiology 2020; 296:E32-40. [CrossRef]

8. Zu ZY, Jiang MD, Xu PP, Chen $W, N i Q Q$, Lu GM, et al. Coronavirus disease 2019 (COVID-19): a perspective from China. Radiology 2020; 296:E15-25. [CrossRef]

9. Ojha V, Mani A, Pandey NN, Sharma S, Kumar S. CT in coronavirus disease 2019 (COVID-19): a systematic review of chest CT findings in 4410 adult patients. Eur Radiol 2020: 30:6129-38. [CrossRef]
10. Kwee TC, Kwee RM. Chest CT in COVID-19: What the radiologist needs to know. RadioGraphics 2020; 40:1848-65. [CrossRef]

11. Adams HJA, Kwee TC, Yakar D, Hope MD, Kwee RM. Chest CT imaging signature of coronavirus disease 2019 infection: In pursuit of the scientific evidence. Chest 2020; 158:1885-95. [CrossRef]

12. Woodring JH, Vandiviere JH, Fried AM. Update: The radiographic features of pulmonary tuberculosis. AJR 1986; 146:497-506. [CrossRef]

13. Libby LS, King TE, LaForce FM, Schwarz MI. Pulmonary cavitation following pulmonary infarction. Medicine (Baltimore) 1985; 64:342-8. [CrossRef]

14. Kelly C, lqbal K, Iman-Gutierrez L, Evans P, Manchegowda K. Lung involvement in inflammatory rheumatic diseases. Best Pract Res Clin Rheumatol 2016; 30:870-88. [CrossRef]

15. Akinosoglou KS, Karkoulias K, Marangos M. Infectious complications in patients with lung cancer. Eur Rev Med Pharmacol Sci 2013; 17:8-18.

16. $\mathrm{Xu} Z$, Pan A, Zhou H. Rare CT feature in a COVID-19 patient: cavitation. Diagn Interv Radiol 2020; 26:380-1. [CrossRef]

17. Pasero D, Sanna S, Liperi C, Piredda D, Branca GP, Casadio $L$, et al. A challenging complication following SARS-CoV-2 infection: a case of pulmonary mucormycosis. Infection 2021; 49:1055-60. [CrossRef]

18. Afrazi A, Garcia-Rodriguez S, Maloney JD, Morgan CT. Cavitary lung lesions and pneumothorax in a healthy patient with active coronavirus-19 (COVID-19) viral pneumonia. Interact Cardiovasc Thorac Surg 2021 ; 32:150-2. [CrossRef]

19. Ackermann M, Verleden SE, Kuehnel M, Haverich A, Welte $T$, Laenger $F$, et al. Pulmonary vascular endothelialitis, thrombosis, and angiogenesis in Covid-19. N Engl J Med 2020; 383:120-8. [CrossRef]

20. Brown KK. Pulmonary vasculitis. Proc Am Thorac Soc 2006; 3:48-57. [CrossRef]

21. Liu K, Zeng Y, Xie P, Ye X, Xu G, Liu J, et al. COVID-19 with cystic features on computed tomography: A case report. Medicine (Baltimore) 2020; 99:e20175. [CrossRef]

22. McGuinness G, Zhan C, Rosenberg N, Azour L, Wickstrom M, Mason DM, et al. High incidence of barotrauma in patients with COVID-19 infection on invasive mechanical ventilation. Radiology 2020; 297:E252-E262. [CrossRef] 